\title{
Iron transportation across the placenta
}

\author{
CLAUDIA M. DE OLIVEIRA ${ }^{1}$, MARCIO N. RODRIGUES ${ }^{1}$ and MARIA ANGÉLICA MIGLINO ${ }^{2}$ \\ ${ }^{1}$ Pós-Graduação de Anatomia dos Animais Domésticos e Silvestres, Universidade de São Paulo (FMVZ-USP), \\ Avenida Prof. Dr. Orlando Marques de Paiva, 87, 05508-270 São Paulo, SP, Brasil \\ ${ }^{2}$ Departamento de Cirurgia, Faculdade de Medicina Veterinária e Zootecnia, Universidade de São Paulo (FMVZ-USP), \\ Avenida Prof. Dr. Orlando Marques de Paiva, 87, 05508-270 São Paulo, SP, Brasil \\ Manuscript received on June 16, 2011; accepted for publication on June 1, 2012
}

\begin{abstract}
According to the classification of placental types among animals, the transfer of iron through the placenta can occur via: absorption connected to transferin through the outer surface of the trophoblast in direct contact with circulating maternal blood; absorption of the erythrocytes by the chorionic epithelium in direct contact with accumulation of blood extravased from haemotophagous areas; absorption by the chorionic epithelium in direct contact with iron enriched secretions from the endometrial glands and absorption by extravasations of the blood in the maternal-fetal surface and the subsequent phagocytosis of the erythrocytes by trophoblast cells described in bovine, small ruminants, canine and feline. The function of erythrophagocytosis observed after the extravasation of blood in the maternal-fetal interface is undefined in several species. Possibly, the iron is transferred to the fetus through the trophoblastic erythrophagocytosis in the hemophogous area of the placenta and also in the endometrial glands. In this literature survey, new methods of studies regarding placental transfer involving iron and other nutrients necessary for survival and maintenance of embryonic fetus to birth are proposed.
\end{abstract}

Key words: endocitosis, iron, phagocytosis, placental hematoma.

\section{INTRODUCTION}

The placenta is a very important organ in the reproduction. It is located in the uterus during pregnancy and is peculiar in mammalian eutherian. This organ plays a key role for the establishment of a special connection between the female and the fetus, and, is characterized for exhibit complex functions (Martal and Cédard 1993).

According to Hafez and Hafez (2004) the placenta is the overlap or fusion of the fetal membranes to the endometrium thus, allowing the occurrence

Correspondence to: Maria Angelica Miglino

E-mail:miglino@usp.br of maternal-fetal physiological changes. This organ differs from other organs and is firmly connected to the embryo and fetus by the umbilical cord. In the fetus, it concentrates many physiological activities which occur individually in the adult animal.

The most common functions of the placenta include: nutrition, protection, respiration and endocrine activity. Due to its high structural diversity among species, many aspects are considered for classification of this organ (Björkman 1982).

For the past decades many researchers have been concerned about the placental transport. Leiser et al. (1997) reported that the endocytosis of the fluid 
substance (pinocytosis) was structurally evident in the units of apical and basal membranes of all endothelial and epithelial placental barriers.

Iron plays an important role in the body, such as transport oxygen in the blood and muscles, and also the transfer of electrons in the metabolism of energy (Linder et al. 2003).

According to the classification of placenta types among animals (Leiser and Kaufman 1994, Perry 1981) and, taking in account the passageway of substances through the inter-hematogenous barrier, the iron transfer can occur via three mechanisms: (i) absorption of iron bonded to transferrin through the outer surface of the trophoblast in direct contact with circulating maternal blood (haemochorial placenta); (ii) absorption of the erythrocytes by the chorionic epithelium in direct contact with accumulation of blood extravased from haemotophagous areas (endotheliochorial and sinepitheliumchorial placentae) and (iii) iron absorption by the chorionic epithelium in direct contact with iron enriched secretions from the endometrial glands (diffuse placentae).

Another mechanism of iron absorption occurs by extravasations of the blood in the maternalfetal interface and the subsequent phagocytosis of the erythrocytes by trophoblast cells described in bovine, small ruminants (goat and sheep), canine and feline as placental hematoma or hemophageal areas (Myagkaya et al. 1984, King 1993, Dantzer 1999).

Many studies have been performed in order to clarify these mechanisms of iron transfer to the fetus. The deficiency of Iron during pregnancy in human and animal's results in long-term deficiency in the new-born, such as high blood pressure, lower brain function and impaired development of the immune system (McArdle et al. 2003, Godfrey and Barker 2000).

The Iron deficiency during pregnancy is a common disorder. The new-born from mothers with iron deficiency are smaller and may present neurological disturbance (Beard et al. 2007, Godfrey and Barker 1995).
The purpose of this review recalls to the description of the mechanisms of Iron transport across the placenta in different species.

IRON

The Iron (together with its carriers and receptors) is an essential nutrient required for a large number of biological processes. Iron is also a toxic component, however there are some mechanisms involved in the maintenance of Iron limits (McArdle et al. 2003).

During pregnancy physiological changes occur and a significant increase of iron requirements in the body. Iron homeostasis takes place at intestinal levels (Linder et al. 2003).

The iron components present in the body can be grouped in two categories: (i) those who have metabolic or enzymatic functions (hemoglobin, myoglobin and enzymes), and, (ii) those associated with iron store. About $76 \%$ of total body iron is present in the hemoglobin, which is composed by four subunits each of it with an associated heme group (Umbelino and Rossi 2006).

For the usage of iron by the body it needs to be captured, internalized and delivered to cells in soluble form. Three protein have the function of capturing, transporting and storing iron thus ensuring its bioavailability. They are transferrin, transferring receptor and ferritin depends (Cançado and Chiattone 2009).

Many factors support the definitive erythropoiesisis induced by junction of pluripotent stem cell with a specialized macrophage in the bone marrow of an adult animal. The stem cell is transformed in the reticular cell that will form the center of an erythroblast islet (Bogair 1991).

According to Gomori (1936), the iron present in the tissues can transpire in two ways: (i) one group of compounds named hemosiderin, where the iron reacts similarly to the compound of insoluble and inorganic iron; (ii) other group of iron compound that can only be demonstrated by chemical destruction such as incineration. 
The iron is absorbed by the intestine and attached to one molecule of protein to be distributed to specific places in the body where it will be utilized or stored.

The major point of iron utilization is the bone marrow, where it is incorporated to the hemoglobin molecule during red blood cells formation. Normally, the iron is stored as hemosiderin, and released in the body by breakdown of red cells and then back again to be stored in normal cases. This system of iron recycling is very efficient and does not allow the occurrence of iron deficiency. The daily iron absorption depends on the daily absorption and also the iron stored in the body (Srai et al. 2002).

According to the placental types existed in animals (Leiser and Kaufman 1994, Perry 1981), and also the passageway of substances through the placental barrier, the transfer of iron in chorioallantoic placenta can occur via three distinct mechanisms; in hemochorial placenta it is observed the iron absorption connected to transferin through the outer surface of the trophoblast in direct contact with the circulating maternal blood.

In sheep, cattle, goats, carnivores and quiroptera it was described another mechanism of iron absorption by extravasation of blood in maternalfetal interface followed by subsequent phagocytosis of erythrocytes by trophoblast cells; this mechanism is denominated placental hematoma or hemophagous areas.

Several studies have been performed in order to clarify the mechanism of iron transfer to the fetus, and, the authors have demonstrated that iron deficiency during pregnancy in humans and animals result in long term disorders in the newborn such as, as high blood pressure, lower brain function and impaired development of the immune system (McArdle et al. 2003).

These studies can also contribute in research related to cancer, because iron is essential for proliferation of cancer cells (Kicic et al. 2001).
MECHANISMS OF IRON TRANSPORT

Several ways of maternal-fetal iron transfer are reported such as: uterine secretions, direct transfer of iron in the serum through membranes of chorioallantoic placenta and phagocytosis of red blood cells extravased by trophoblast in the interior of hemophagous organs, or hematoma followed by releasing of iron from maternal hemoglobin in fetal circulation.

In species without hemochorial placenta the transfer of iron seems to be by releasing of maternal hemoglobin from red blood cells extravased as found in hematoma and similar phagocytic areas of chorioallantoic membrane (Seal et al. 1972).

According to Schröder (1995), the epitheliochorial and endotheliochorial placentas exhibit specialized areas in which maternal red blood cells are able to penetrate into the trophoblast cells. In the trophoblast cells, the maternal cells are broken by phagossomes and the iron is released in the cytoplasm being stored as ferritin or passing directly to the fetal capillaries.

The epithelium of the "arcade zone" includes the region of the outer surface of maternal villi, which is in contact with the base of fetal villi. It is a modified epithelium since it shows evidence of absorptive phagocytic and secretor characteristics with the role of nourishing the fetus. These structures were also observed in experiments with buffaloes (Pereira et al. 2001), cows (Wimsatt 1980), goats and sheep (Lawn et al. 1969).

The processes of endocytosis, transcytosis and signal transduction are performed by plasma membrane invaginations called caveolae. The caveolae are found in the apical surface of cells including in the trophoblast (Enders et al. 1983). They are also involved directly with the internalization of membrane components (proteins of glycosphingolipids and glicoesfingofosfatoidil inositol anchoring), extracellular bindings, bacterial toxins and non-enveloped viruses. 
In the bases of chorionic villi of the sheep placenta, the occurrence of large quantities of maternal blood extravased between the corium and apical segments of inter-criptal septa results in hematoma; contrary situation is observed in most ruminants where the maternal erythrocytes are phagocyted by adjacent trophoblast cells, which eventually accumulate in intra-cytoplasmatic deposits of non-ferruginous hematogenous pigments.

It is believed that this hematoma is resultant from the maternal capillaries opening in the surface of intervillous septa of the adjacent trophoblast (Wimsatt 1950).

According to Lawn et al. (1969) descriptions, in the goat and sheep placenta, the specialized region of the placentome where maternal blood extravasation and phagocytosis occur, have the function of supplying the needs of iron to the fetus.

In the ruminant placenta, the placenta hematoma are formed in the vicinity of the trophoblast cells located in the arcade zone, where the maternal

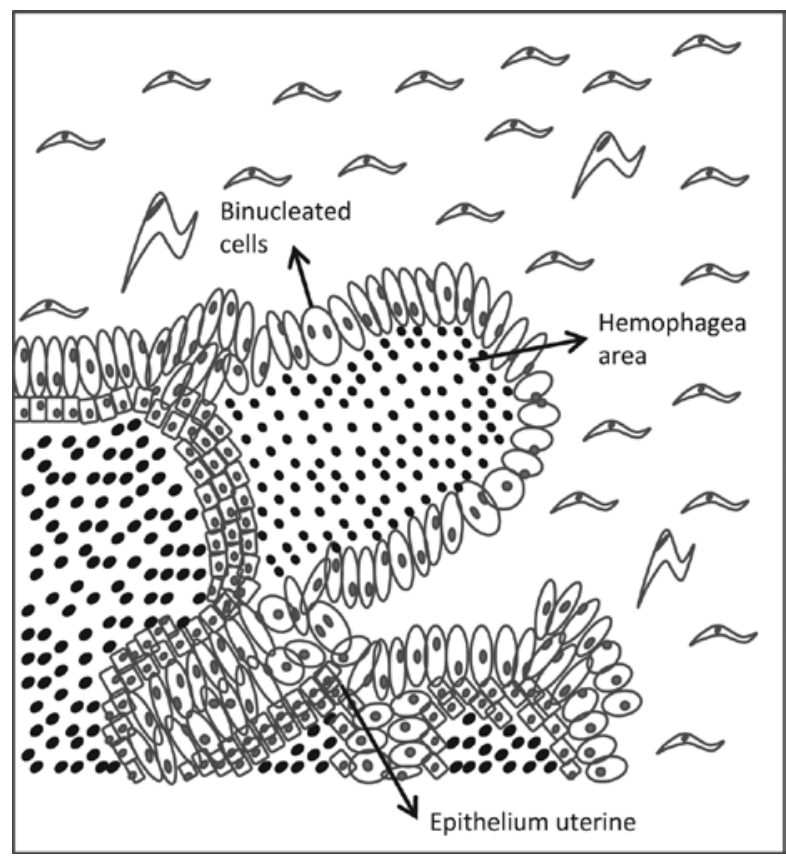

Figure 1 - Outline of the mechanism of absorption of iron in biggest increase, through the hemophagea epithelium villus sampling the area resulting from a maternal blood extravasation occurring absorption of erythrocytes by epithelium villus sampling in the trophoblast. erythrocyte will be encompassed by trophoblast cells and reduced to irregular masses of non-ferruginous pigment inside of its cytoplasm. Both, the binucleated and the columnar trophoblast cells are part of this process, but the binucleated cells are perhaps less efficient in the phagocytosis than the columnar cells, because their cytoplasm is almost invariable and contain less corpuscles or pigmented bodies than the columnar cells (Figure 1) (Wimsatt 1980).

Cazerta et al. (2007) reported that in the cows the epithelium of arcade zone is modified suggesting secretory, absorptive and phagocytic characteristics that facilitate fetal nutrition. Additionally, hemophagea area of the bovine placenta seems to be important sites of iron transfer and could be involved in fetal hematopoiesis.

Pereira et al. (2010) cited in their studies, that the erythrophagocytosis in buffaloes occur at nine to ten months of pregnancy being a notable feature of this region (placentome) of maternalfetal exchange.

Wooding et al. (2000) reported that the iron transport in the equine placenta comprise a restricted region being transferred by uteroferrin molecules found in uterine secretions during pregnancy, in a similar process that occur in the ruminants.

McDowell et al. (1982) described that the iron transport in the equine placenta occurs via two mechanisms: the trophoblast and uterine glands.

In the swine the uteroferrin is synthesized in the endometrium located exclusively in the nonciliated glandular epithelium. The uteroferrin is present in lumen of the glands and in the placenta villi: its absorption occurs in the cells of chorionic epithelium (Figure 2) (Raub et al. 1985).

Several authors suggested that the hematophogue areas or placenta hematoma have the important function of iron transfer from mother to fetus (Lawn et al. 1969).

In this literature review survey new methods of placenta transport involving iron and other nutrients required for surviving and embryonic 


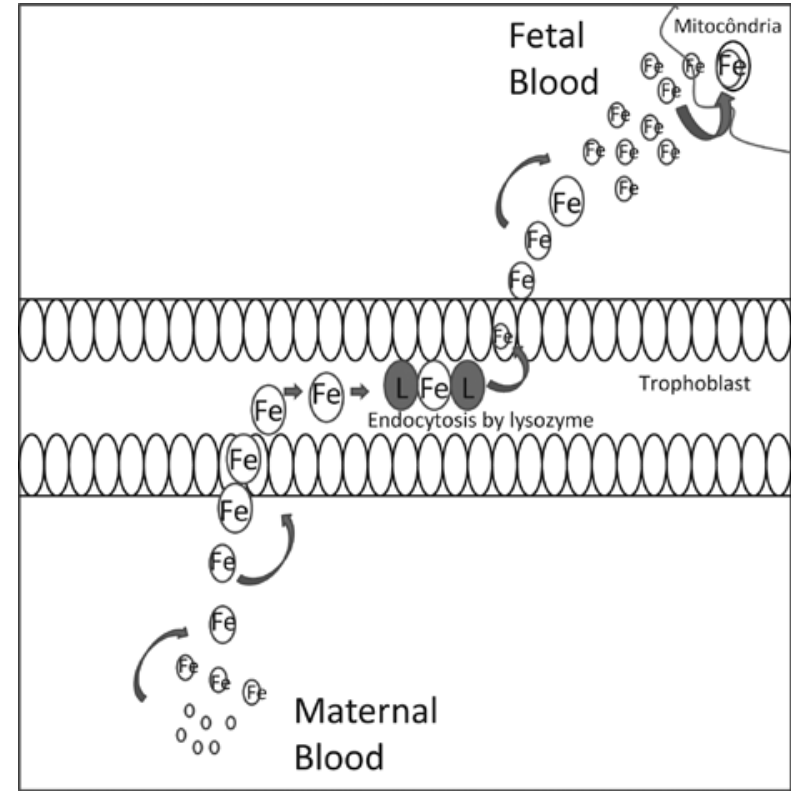

Figure 2 - Outline the mechanism of absorption of iron through the outer surface of the trophoblast through the presence of receptors for transferrin, in which iron is bound, the complex of transferrin receptoriron is incorporated into the cytoplasm by endocytosis. in black cells the endocytic vacuole fuses with lysozyme, where the acid $\mathrm{pH}$ in iron is released from the heme transferrina.

maintenance until the conception. Adequate nutritional manipulation in all species mentioned in this review, might be a determinant factor for the success of iron absorption. Therefore, it can be assumed that iron absorption occur via two mechanisms, by endocytosis through iron receptors located in trophoblast membrane and other process through phagocytosis of substances arising from the maternal side such as blood (erythrocytes) maternal cytoplasm, degenerated uterine tissue and disintegrated blood.

\section{RESUMO}

De acordo com a classificação dos tipos de placenta existentes entre os animais e em relação com a passagem de substâncias pela barreira inter-hemática, a transferência de ferro pode ser realizada através da: absorção de ferro ligado a transferrina através da superfície externa do trofoblasto em contato direto com o sangue materno circulante; absorção de eritrócitos pelo epitélio coriônico em contato direto com acúmulos de sangue materno extravasado em áreas hematófagas, absorção de ferro pelo epitélio coriônico em contato direto com secreções ricas em ferro provenientes de glândulas endometriais e fagocitose dos eritrócitos pelas células trofoblásticas, a qual foi descrita em bovinos, pequenos ruminantes, caninos e felinos como hematomas placentários ou áreas hemófogas. A função da eritrofagocitose observada após o extravasamento de sangue na interface materno-fetal é indefinida em várias espécies. Possivelmente, o ferro é transferido para o feto através da eritrofagocitose trofoblástica na área hemophogous da placenta e também nas glândulas endometriais. Após o levantamento desta revisão bibliográfico são propostos novos métodos de estudos sobre o transporte placentário envolvendo além do Ferro outros nutrientes necessários a sobrevivência e manutenção embrionária fetal até o nascimento.

Palavras-chave: endocitose, ferro, fagocitose, hematoma placentário.

\section{REFERENCES}

Beard J, Ungar EL, Bianco Le, Paul T, Rundle SE and JONES BC. 2007. Early postnatal iron repletion overcomes lasting effects of gestation iron deficiency in rats. Jou Nutr 137: 1176-1182.

BJÖRKMAN N. 1982. Placentação. In: DELMANN HP AND BROWN EM. Histologia Veterinária. Rio de Janeiro: Guanabara Koogan, p. 279-294.

BogaIR N. 1991. The Bessis reticular cell, the hemoglobin: a hypothesis. Med Hypotheses 34(2): 105-110.

CANÇADO RD AND ChiatTone CS. 2009. Aspectos atuais do metabolismo do ferro. Rev Bras Med 46(1): 1-8.

Cazerta SMM, Miglino MA, Marques RS, Vulcano M AND PEREIRA FTV. 2007. Caracterização das áreas hemófagas da placenta bovina. Pesq Vet Bras 27(6): 229-235.

DANTZER V. 1999. Epitheliochorial placentation. In: Knobil E CANÇADO RD AND CHIATTONE CS. 2009. Aspectos atuais do metabolismo do ferro. Rev Bras Med 46(1): 1-8.

MeILl JD. Ency Reprod, San Diego: Academic Press 1: 18-28.

Enders AC, HeNDrickX AG AND SCHLAFKE S. 1983. Implantation in the rhesus monkey: initial penetration endometrium. Ame Jou Anat 167: 275-298.

GODFREY KM AND BARKER DJP. 1995. Maternal nutrition in relation to fetal and placental growth. Eur J Obstet Gynecol Reprod Biol 65: 15-22.

GODFREY KM AND BARKER DJP. 2000. Fetal nutrition and adult disease. Am J Clin Nutr 71(5): 1344s-1352s. 
GOMORI G. 1936. A microtechnical demonstration of iron. A criticinm of this methods. Am J Pathol XII: 655-665.

JAINUDEEN MR AND HAFEZ EES. 2004. Gestação, Fisiologia Pré-natal e Parto. In: HAFEZ EES (Ed), Reprod Anim, $7^{\mathrm{a}}$. ed., Barueri, SP: Manole, p. 141-155.

KICIC A, CHUA AC AND BAKER E. 2001. Effect of iron chelators on proliferation and iron uptake in hepatoma cells. Cancer 92(12): 3093-3110.

KING BF. 1993. Comparative anatomy of placental barrier. Bibliotheca Anatomica (Karger, Brasil) 22: 13-28.

LAWN A, CHIQUOINI AD AND AMOROSO EC. 1969. The development of the placenta in the sheep and goat: na electron microscope study. J Anat 105(3): 557-578.

LEISER R AND KAUfMan P. 1994. Placental structure: in a comparative aspect. Exp Clin Endocrinol 102: 122-134.

Leiser R, Krebs K, KLISCH K, EBERT B, DANTZER V, Schuler G AND HOFFMANN B. 1997. Fetal and microvasculature of the bovine placentome in the second half of getation. Jou Anat 191: 517-527.

Linder MC, ZEROUNIAN NR, MORUJA M AND MALPE R. 2003. Iron and copper homeostasis and intestinal absorption using the Caco2 cell model. BioMet 16: 145-160.

MARTAL J AND CÉDARD L. 1993. Endocrine functions of the Placenta. In: THIBAULT C, LEVASSEUR MC AND HUNTER RHF. Reprod Mamm Man Ellipses, Paris, p. 435-459.

MCARdle HJ, DANZEISEN R, Forret C AND GAMBling L. 2003. The role of the placenta in iron transfer from mother to fetus and the relationship between iron status and fetal outcone. BioMet 16: 161-167.

McDowell KJ, Sharp DC, Fazleabas A, Roberts RM AND BAZER FW. 1982. Partial characterization of equine uteroferrin like protein. J Reprod Fert 32: 329-334.

Myagkaya GL, Schonargel K, VAN VEen H AND EVERTS V. 1984. Electron microscopic atudy of the localization of ferric iron in chorionic epithelium of the sheep placenta. Placenta 5(6): 551-558.
Pereira FTV, Braga FC, Burioli KC, KFoUry JR, Oliveira LJ, PAPA PC, CARVAlHo AF, AmbrósIo CE, BAZER FW AND MigLINO MA. 2010. Transplacental Transfer of Iron in the Water Buffalo (Bubabul bubalis): Uteroferrin and Erythrophagocytosis. Reprod Dom Anim 45(5): 907-914.

PEREIRA FTV, Miglino MA, BEVILACQUa E AND CARVAlHo AF. 2001. Aspectos morfológicos dos hematomas placentários da placenta do búfalo (Bubalus bubalis bubalis Linnaeus, 1758). Braz J Vet Res Anim Scie 38(4): 151-154.

PERRY JS. 1981. The mammalian fetal membranes. J Reprod Fert 62: 321-335.

RAUB TJ, BAZER FW AND ROBERTS RM. 1985. Localization of iron transport glycoprotein, uteroferrin, in the porcine endometrium and placenta by using immunocolloidal gold. Anat Embryo 171: 253-258.

SCHRÖDER HJ. 1995. Comparative aspects of placental exchange functions. Euro J Obste Ginecol Biol 63: 81-90.

SEAL US, SinHA AA AND DOE RP. 1972. Placental iron transfer: Relationship to placental anatomy and phylogeny of the mammals. Ame Jour Anat 134(2): 263-269.

SRAI SKS, BOMFORD A AND MCARDLE HJ. 2002. Iron transport across cell membranes: molecular understanding of duodenal and placental iron uptake. Best Prac Resear Clin Haem 15(2): 243-259.

UMBELINO DC AND Rossi EA. 2006. Deficiência de ferro: conseqüências biológicas e propostas de prevenção. Rev Ciênc Farm Básica Apl 27(2): 103-112.

WiMSATT WA. 1950. New histological observations on the placenta of the sheep. Am J Anat 87: 391-458.

WiMSATT WA. 1980. Observations on the morphologenesis cytochemistry, and significance of the binucleate giant cells of the placenta of ruminants. Am J Anat 159(2): 209-243.

Wooding FBP, Morgan G, Fowden AL AND ALLEN WR. 2000. Separete Sites and Mechanisms for Placental Transport of Calcium, Iron and Glucose in the Equine Placenta. Placenta 21: 635-645. 